\title{
PENDIDIKAN AGAMA ISLAM TERPADU PADA SMPIT BINA UMAT YOGYAKARTA ${ }^{1}$
}

\author{
Soemanto \\ Puslitbang Pendidikan Agama dan Keagamaan | Balitbang dan Diklat Kemenag RI \\ Jl. MH Thamrin No.06 Jakarta Pusat | Email: soemantotaruno@yahoo.com
}

\begin{abstract}
Around the 2000s many institutions labeled as Islamic Integrated Schools (Sekolah Islam Terpadu/SIT) emerged. They were quite attractive to the public. One of the concepts of Integrated Islamic School is a one that uses a combined approach of general and religious educations into a fine integration in terms of curriculum, teaching methods, education of Aqliyah (rational), Ruhiyah (spiritual) and jasadiyah (physical). This study using qualitative approach aims to describe what and how the integration model in Islamic Junior Secondary Education (SMPIT) Bina Umat are all about. The findings suggest that there are at least four components that comprise essential elements of integration in SMPIT Bina Ummah. The first is the integration with the environment. The second is the integration in terms of curriculum aspects. The third is the integration with traditional model of boarding school education. And the fourth is the integrated learning both inside and outside the classroom.
\end{abstract}

Keywords: Model, Integrated Islamic School, Curriculum

\section{Abstrak}

Sekitar tahun 2000-an bermunculan Sekolah-sekolah berlabel Islam Terpadu (SIT). Model sekolah ini cukup diminati masyarakat. Salah satu konsep Sekolah Islam Terpadu adalah sekolah yang menerapkan pendekatan penyelenggaraannya memadukan pendidikan umum dan pendidikan agama menjadi suatu jalinan baik dalam kurikulum, metode pembelajaran, pendidikan aqliyah, ruhiyah dan jasadiyah. Penelitian dengan teknik kualitatif ini bertujuan untuk mendeskripsikan apa dan bagaimana model keterpaduan pada Sekolah Menengah Pertama Islam Terpadu (SMPIT) Bina Umat. Temuannya menunjukkan bahwa paling tidak ada empat komponen yang menjadi unsur pokok keterpaduan pada SMPIT Bina Umat. Pertama keterpaduan dengan lingkungan. Kedua, keterpaduan pada aspek kurikulum. Ketiga, keterpaduan dengan tradisi pendidikan model Pesantren. Dan, keempat, keterpaduan pembelajaran di dalam dan di luar kelas.

Kata Kunci: Model, Sekolah Islam Terpadu, Kurikulum

\section{PENDAHULUAN}

Awal tahun 2000 mulai marak bermunculan model pendidikan alternatif yang dikenal dengan Sekolah Islam Terpadu. Model sekolah ini cukup diminati masyarakat, terutama kalangan menengah ke atas. Model pendidikan ini tidak hanya hadir di kota besar seperti Jakarta, Bandung, surabaya, namun juga di hampir setiap provinsi di Indonesia dapat dijumpai. Belakangan ini banyak muncul di pelosok pedesaan.

Sekolah Islam Terpadu pada hakekatnya adalah sekolah yang mengimplementasikan konsep pendidikan Islam berlandaskan AlQuran dan As sunnah. Dalam aplikasinya Sekolah Islam Terpadu diartikan sebagai

${ }^{1}$ Penelitian ini berangkat dari "Desain Operasional Penyelenggaraan Pendidikan Agama Islam Terintegrasi yang Dilaksanakan Puslitbang Pendidikan Agama dan Keagamaan Tahun 2013, dengan pengumpulan data dibantu oleh Said Amin dan Sri Rejeki. Untuk itu penulis mengucapkan terima kasih sebesar-besarnya. 
sekolah yang menerapkan pendekatan penyelenggaraannya dengan memadukan pendidikan umum dan pendidikan agama menjadi suatu jalinan kurikulum. Sekolah Islam Terpadu juga menekankan keterpaduan dalam metode pembelajaran sehingga dapat mengoptimalkan ranah kognitif, afektif dan psikomotorik. Sekolah Islam Terpadu juga memadukan pendidikan aqliyah, ruhiyah dan jasadiyah. Dalam penyelenggaraannya memadukan keterlibatan dan partisipasi aktif lingkungan belajar yaitu sekolah, rumah dan masyarakat. $^{2}$

Pada sisi lain Sekolah Islam Terpadu diartikan sebagai sekolah yang menerapkan pendekatan penyelenggaraan dengan memadukan pendidikan umum dan pendidikan agama menjadi satu jalinan kurikulum. Dengan pendekatan ini, semua mata pelajaran dan semua kegiatan sekolah tidak lepas dari bingkai ajaran dan pesan nilai Islam. Tidak ada dikotomi, tidak ada keterpisahan, tidak ada "sekularisasi" di mana pelajaran dan semua bahasan lepas dari nilai dan ajaran Islam, ataupun "sakralisasi" di mana Islam diajarkan terlepas dari konteks kemaslahatan kehidupan masa kini dan masa depan. Pelajaran umum, seperti matematika, IPA, IPS, bahasa, pendidikan jasmani/kesehatan, keterampilan dibingkai dengan pijakan, pedoman dan panduan Islam. Sementara pelajaran agama, diperkaya dengan pendekatan konteks kekinian dan kemanfaatan, dan kemaslahatan ${ }^{3}$

Dalam benak masyarakat ada dikotomi antara pendidikan agama dengan pendidikan umum. Pendidikan umum diwakili oleh sekolah, sedangkan sekolah agama diwakili pesantren. Bahkan menurut Machnun Husein, pendidikan di Indonesia bisa diklasifikasikan menjadi dua, yaitu (1) ta'lim dan (2) ta'dib. Ta'lim lebih berorientasi kepada akal, ijazah,

${ }^{2} \mathrm{http}: / / \mathrm{sditsalmanalfarisi} 2$. wordpress. com/2012/02/07/pengertian-sekolah-islam-terpadu/ diakses tanggal 10 Februari 2014.

http://smait.nurhidayahsolo.com/berita-180konsep-sekolah-islam-terpadu.html diakses tanggal 10 Februari 2014. dan materi. Sedangkan ta'dib lebih mengarah kepada pembentukkan budi luhur, rasa dan adab. $^{4}$

Kehadiran sekolah Islam ataupun sekolah Islam terpadu mencoba memberikan jawaban terhadap kekurangan yang terjadi pada sekolah, yang pada umumnya masih belum optimal menciptakan keluaran sumber daya manusia yang berwawasan iptek dan sekaligus imtak. Sekolah belum dapat secara optimal menghasilkan sumber daya manusia yang memiliki kecerdasan yang integrated, yang lengkap, yang memadukan kecerdasan intelektual dengan kecerdasan emosional dan kecerdasan spiritual yang bersumber pada ajaran agama Islam.

Sekitar tahun 1980an di Indonesia berkibar nama Ivan Illich, penulis buku Descholing Society. Penulis buku ini menawarkan gagasan "bebas dari sekolah". Ia menawarkan formula yang substansinya kurang lebih sama dengan pendidikan model pesantren tradisional. Belajar di pesantren penuh dengan suasana kekeluargaan. Suasana yang demikian ini tidak ditemukan di sekolah. Di sekolah interkasi kognitif lebih banyak porsinya. Di Indonesia malahan menurut A.H Johns, lembaga-lembaga pesantren itulah yang paling menentukan watak keislaman dari kerajaan-kerajaan Islam, dan yang memegang peranan paling penting bagi penyebaran Islam sampai ke pelosokpelosok. $^{5}$

Kehadiran sekolah Islam terpadu yang semakin semarak tersebut juga dimaksudkan untuk menjawab dan menghilangkan dikotomi antara pendidikan agama dengan pendidikan umum. Walaupun pendidikan agama berlangsung di sekolah, tapi masih menekankan pada aspek pembelajaran yang normatif-tekstual, lebih banyak pada

${ }^{4}$ Abd. Majid. 2013. Pendidikan Berbasis Ketuhanan, Bandung: VC. Maulana Media Grafika, cetakkan ke 3, h. 129.

${ }^{5}$ Zamakhsyari Dhofier. 1982. Tradisi Pesantren, Studi Tentang Pandangan Hidup Kyai, Jakarta: LP3ES, h. 17. 
pengembangan ranah kognitif, tapi miskin pada pembentukan sikap dan perilaku siswa.

Sekolah Islam Terpadu yang berkembang di masyarakat meliputi semua jenjang pendidikan, yaitu mulai dari sekolah dasar (SD IT), sekolah menengah pertama (SMP IT), sampai sekolah menengah atas (SMA IT). Sebagian sekolah tersebut melabeli dengan sebutan Islam Terpadu (IT), namun ada juga yang tanpa melabeli dengan tulisan IT, kendati di dalam penyelenggaraan pendidikannya melaksanakan pengintegrasian pendidikan agama ke dalam semua aspek pendidikan.

Dari pengertian di atas, dapat ditarik kesimpulan bahwa Sekolah Islam ataupun Sekolah Islam Terpadu adalah sekolah yang diselenggarakan dengan memadukan secara integratif ajaran dan nilai-nilai luhur agama Islam dalam struktur kurikulum dengan menggunakan pendekatan pembelajaran efektif dan efisien, yang mengedepankan keseimbangan pencapaian aspek kognitif, afektif, dan psikomotorik melalui pelibatan yang optimal dan kooperatif antara sekolah, keluarga dan masyarakat dalam membangun karakter dan kompetensi yang harus dimiliki siswa.

Sekolah berlabel Islam ataupun sekolah Islam terpadu dibangun dengan paradigma keilmuan yang utuh yang berlandaskan pada filosofi yang menyandarkan pada kesadaran bahwa Allah-lah yang menciptakan alam semesta ini dengan Maha Sempurna. Masingmasing ciptaan-Nya tersebut saling terkait dan mempunyai perbedaan dan manfaat, namun semuanya tunduk dan patuh pada sunnatullah yang telah ditetapkan. Dengan kata lain, Allah swt. sebagai sumber ilmu pengetahuan.

Sekolah Islam ataupun sekolah Islam terpadu bertujuan membina siswa untuk menjadi insan yang bertakwa, cerdas, berakhlak mulia, serta memiliki keterampilan atau skills yang akan memberi manfaat dan kebaikan bagi umat manusia, serta sebagai manusia yang memiliki akidah yang bersih, dapat melaksanakan ibadah yang benar, memiliki kepribadian yang matang, bersikap mandiri, memiliki kecerdasan dan pengetahuan, sehat dan kuat, bersungguh-sungguh, disiplin, tertib, cermat, hemat, dan bermanfaat.

Penelitian ini bertujuan untuk men deskripsikan apa dan bagaimana model pengintegrasian Pendidikan Agama Islam ke dalam sistem pendidikan sekolah yang berlangsung di SMP IT Bina Ummat.

\section{Metodologi Penelitian}

Penelitian ini merupakan penelitian kualitatif. Karena penelitian ini merupakan penelitian dengan pendekatan kualitatif, maka instrumen pengumpulan data adalah peneliti itu sendiri. Obyek yang menjadi sasaran penelitian ini adalah sekolah Islam Terpadu yang penyelenggaraannya berada dalam pondok pesantren.

SMP IT Bina Umat terletak sekitar 30 Km dari Pusat Kota Yagyakarta, tepatnya di Dukuh Setran, Desa Sumberarum, Kecamatan Moyudan, Kabupaten Sleman, Provinsi Daerah Istimewa Yogyakarta. Lokasi ini sangat cocok bagi lembaga pendidikan model pendidikan pondok pesantren, karena jauh dari kebisingan dan hiruk pikuk perkotaan, sehingga memungkinkan siswa yang menuntut ilmu di sekolah ini dapat belajar dengan tenang.

\section{Sejarah Pendidikan}

Sekitar 2001 tujuh aktifis, yaitu Mustofa Ismail, Gazali Mukri, Sukarno, Syamsul Hadi, Purbudi Wahyuni, Nurhayati dan Nazif, ingin melakukan pencerdasan masyarakat melalui lembaga pendidikan. Untuk memulai aktifitas tersebut, mereka yang terdiri dari alumni perguruan tinggi di Timur Tengah dan beberapa orang tokoh masyarakat di Yogyakarta pada tanggal 2 Mei 2001 mendirikan yayasan yang diberi nama dengan Yayasan Bina Umat. Aktifitas awal dari Yayasan adalah membuka Kelompok Bimbingan Ibadah Haji (KBIH) dan Umrah Bina Umat. 
Diawali dengan memberikan pendidikan agama kepada anak-anak usia sekolah SMP dan SMA yang berjumlah 27 orang, bertempat di Masjid Al-Ikhlas di sebelah utara terminal Giwangan Yogyakarta. Anak-anak yang dididik di tempat ini adalah anak-anak yang tinggal menggelandang di sekitar terminal. Mereka adalah anak-anak yang ditinggalkan orangtuanya begitu saja, dan akhirnya menjadi anak jalanan. Untuk kegiatan ini butuh biaya, maka KBIH Bina Umat mengambil keputusan bahwa seluruh keuntungan dari KBIH ini 100\% digunakan untuk membiayai kegiatan proses belajar mengajar di Mesjid Al-Ikhlas ini.

Seiring berjalannya waktu, H. Bajuri ${ }^{6}$ yang memiliki satu rumah dan satu masjid di Dukuh Setran, Desa Sumberarum, Kecamatan Moyudan, Kabupaten Sleman Yogyakarta mewakafkan tanah dan rumahnya kepada Yayasan Bina Umat untuk dipergunakan sebagai tempat untuk proses belajar anak-anak yang semula belajar di Masjid Al-Ikhlas Mrican Yogyakarta. Sementara masjid diwakafkan kepada masyarakat setempat. Sampai sekarang

${ }^{6}$ Pada saat ada urusan ke kantor notaris---Sukarno di Sleman, pada saat yang bersamaan datang dua atau tiga orang ke kantor yang sama, dengan memakai kopiah putih (kopiah haji). Katika H. Bajuri menanyakan kegaiatan apa yang ditangani kepada tamu tersebut, mereka menjawab bergerak di bidang sosial keagamaan. Spontan H. Bajuri menjawab: "aku duwe omah nek dienggo boleh" (saya punya rumah kalau mau dimanfaatkan boleh). Mereka bertiga tidak langsung menerima begitu saja. Setelah melakukan survey baik rumahnya yang di Klaten, maupun rumah anaknya yang di Solo, barulah wakaf tersebut kemudian diproses. Yang diwakafkan adalah tanah dan rumah, sementara masjid sudah diwakafkan ke masyarakat setempat terlebih dahulu, tepatnya tahun 1977. Kalau rumah dan tanah diwakafkan tahun 2000an. H. Bajuri adalah pensiunan pegawai Kementerian Keuangan. Aktifis Muhammadiyah, orangtuanya tokoh agama setempat dan lulusan pesantren tebu ireng. H. Bajuri anak ke lima. Orangtuanya bernama Kasan Pawiro, yang nama kecil bernama Kayun. Saat penelitian ini berlangsung, usianya sekitar 86 tahun. Tinggal di Klaten. Sebagai pegawai Kementerian Keuangan H. Bajuri sering berpindah tugas. Ketika tugas di Pekanbaru Riau tahun 1958, beliau membuat masjid, yang diberi nama Masjid Ataqwa, sampai sekarang konon masjid tersebut masih dimanfaatkan oleh masyarakat. Sepulang tugas di Ambon, dan kemudian bertugas di Solo sekitar tahun 1977, H. Bajuri membangun masjid di desanya, yakni Dukuh Setran, yang nantinya diwakafkan kepada masyarakat setempat. masjid tersebut juga dimanfaatkan oleh SMP Bina Umat.

Sejak menerima wakaf itulah, proses belajar mengajar pindah dari Masjid Al-Ikhlas dekat terminal Giwangan Yogyakarta ke rumah keluarga yang diwakafkan oleh $\mathrm{H}$. Bajuri beserta seluruh siswanya yang berjumlah 17 orang. Di sana kemudian digabungkan dengan 20 orang santri yang dibawa oleh Al-hafiz Ustadz Abu Umar dari Demak dan ditambah dengan anakanak lulusan Sekolah Dasar yang ada di sekitar rumah wakaf $\mathrm{H}$. Bajuri. Ustadz Abu Umar sebelumnya adalah ustadz di pesantren milik keluarganya yaitu Pesantren Bustanu Musyaqil Qur'an di Demak Jawa Tengah. Di rumah yang diwakafkan oleh H. Bajuri inilah Ustadz Abu Abu Umar mulai mengasuh anak-anak untuk belajar Tahfiz dan Kitab.

Maraknya Sekolah Islam Terpadu pada waktu itu menginspirasi Yayasan Bina Umat untuk mendirikan sekolah formal yang diberi nama SMP IT Bina Umat. Tepatnya pada tahun 2003. Pada waktu itu jumlah siswa sudah tidak bisa lagi ditampung di rumah wakaf. Maka pengurus Yayasan meminjam gedung SD Inpres yang sudah tidak digunakan yang berada di desa tersebut. Waktu itu SMP IT Bina Umat belum memiliki ijin operasional. Setelah dua tahun berjalan barulah Dinas Pendidikan Kabupaten Sleman mengeluarkan ijin operasional bagi SMP IT Bina Umat. tepatnya pada tahun 2005.

Setelah ijin operasional dari Dinas Pendidikan Kabupaten Sleman keluar pada tahun 2005, maka siswa-siswa SMP IT Bina Umat dapat mengikuti Ujian Nasional daan menginduk di SMP Moyudan Sleman Yogyakarta. Ini merupakan pertama kalinya SMP IT Bina Umat mengirimkan siswasiswanya untuk mengikuti Ujian Nasional. Semua siswa yang mengikuti Ujian Nasional lulus $100 \%$ dan bahkan beberapa siswa masuk kategori 10 besar untuk DIY. Ini tidak hanya mengangkat nama SMP IT Bina Umat, tetapi juga mengangkat nama SMP Negeri Moyudan sebagai sekolah induk penyelenggara Ujian 
Nasional. Sekarang ini SMP IT Bina Umat berada di peringkat ke-5 sekolah terbaik di Kabupaten Sleman dan peringkat ke-19 sekolah terbaik se-Provinsi Daerah Istimewa Yogyakarta.

Visi SMPIT Bina Umat adalah mencetak generasi yang unggul dalam ilmu pengetahuan dan teknologi yang berlandaskan iman dan takwa.

Sementara misinya adalah: 1). Menyelenggarakan kegiatan pendidikan yang memadukan antara model pendidikan nasional dan pendidikan pondok modern. 2). Meletakkan dasar-dasar pendidikan yang menyeluruh dan seimbang pada: a). Aspek kognitif, psikomotorik, dan afektif, b). Aqliyah (fikir), ruhiyah (rohani), dan jasadiyah (fisik). 3). Memadukan iptek dan imtak.

\section{Tujuan Pendidikan}

SMP IT Bina Umat ini didirikan bertujuan: 1). Melahirkan calon-calon pemimpin-pemimpin yang bertakwa dan bermanfaat bagi sekalian alam. 2). Malahirkan alumni-alumni yang menguasai Imtak dan Iptek, 3). Melahirkan siswa yang memiliki kepribadian yang mandiri. 4). Melahirkan alumni yang membiasakan kebaikan dalam kehidupan

\section{Guru dan Siswa}

Tenaga pengajar dan ustadz terdiri dari para lulusan perguruan tinggi dalam dan luar negeri, seperti dari Universitas Al-Azhar Mesir, Madina University, UGM, UNY, UIN Sunan Kalijaga, Universitas Ahmad Dahlan, PP Gontor, PP Al-Amin, PP Ma'ruf Jepara, dan juga lulusan Pondok Pesantren Bina Umat itu sendiri.

Siswa-siswa yang belajar di SMP IT Bina Umat saat penelitian ini berjalan berjumlah 307 orang, mereka berasal dari berbagai daerah di Indonesia. Mayoritas berasal dari provinsi di Pulau Jawa, seperti dari DI Yogyakarta, Jawa Tengah, Jawa Timur, Jawa Barat dan sebagian lagi berasal dari luar Jawa, antara lain berasal dari Sumatera, Sulawesi, Nusa Tenggara dan Kalimantan.

Latar belakang ekonomi siswa berasal kelas menengah. Sebagian besar (41.4\%) pekerjaaan orangtuan adalah PNS. Sementara hanya sebagian kecil (5.1\%) yang menyatakan pekerjaan orangtuanya adalah petani dan sebagai pedagang sebanyak (8.1\%) Adapun bendidikan orangtua siswa bisa diperiksa pada grafik berikut.

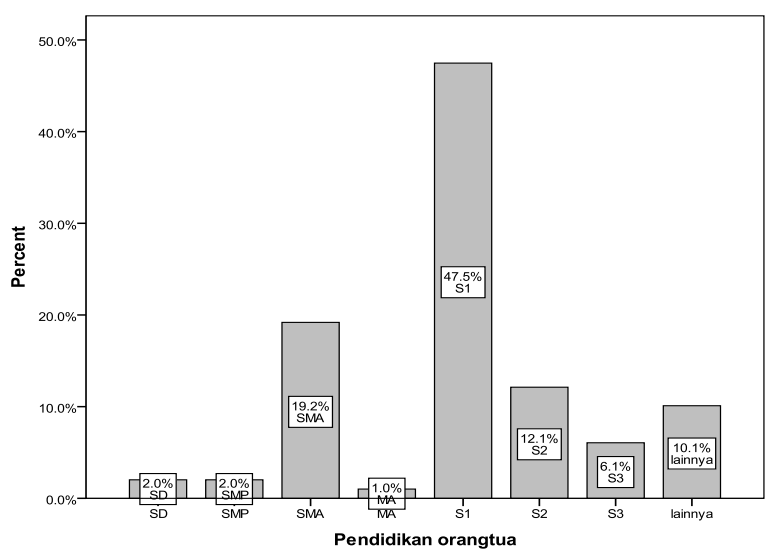

Dari grafik di atas terlihat bahwa sebagian besar (59.7\%) pendidikan orangtua siswa adalah sarjana, baik S1, S2 sampai dengan S3. Grafik tersebut memberikan pengertian kepada kita bahwa peminat untuk memasukkan anaknya ke SMP Bina Umat merupakan pilihan rasional. Pilihan ini tentu didasari banyak pertimbangan, salah satunya adalah faktor agama Islam tentu sangat dominan. Parkes mengemukakan teorinya bahwa pandangan keagamaan suatu kelompok masyarakat sangat berpengaruh dalam nenentukan sikap dan perilaku. ${ }^{7}$ Walaupun tidak ada data, peneliti berkeyakinan tentu tidak ada orangtua yang beragama selain Islam yang memasukkan anaknya ke SMP Bina Umat ${ }^{8}$. informasi lainnya adalah bahwa sebagian besar (81.8\%)

${ }^{7}$ Alwi Shihab. 1998. Islam Inklusif, Bandung: Mizan, cetakan ke tiga, h. 159.

${ }^{8}$ Setelah dikonfirmasi baik kepada kepala sekolah maupun wakil kepala sekolah melalui telepon celuler pada tanggal 9 Juni 2014, memang tidak ada orangtua siswa yang beragama selain Islam. 
responden mengaku masuk ke SMP Bina Umat atas kemauannya sendiri. Hanya sebagian kecil (15.2\%) saja yang merupakan pilihan orangtua.

\section{Sarana dan Prasarana}

Sarana dan prasarana yang dimiliki oleh SMP IT Bina Umat cukup memadai antara lain, 1) gedung belajar putra, 2) gedung belajar putri. 3) gedung asrama putra. 4) gedung asrama putri. 5) gedung laboratorium IPA. 6) gedung laboratorium komputer dan internet. 7) masjid dan musala. 8) dapur umum. 9) ruang koperasi. 10. ruang kantin. 11) gedung perkantoran. Selain bangunan gedung juga fasilitas olah raga disiapkan, antara lain, 1) lapangan bola basket, 2) lapangan bola volley, 4) lapangan bulu tangkis, 5) lapangan tenis meja. Untuk lapangan sepak bola, menggunakan lapangan milik desa.

\section{Konsep Keterpaduan}

\section{Keterpaduan dengan Lingkungan}

Keberadaan SMP IT Bina Umat dalam dukuh Setran menyatu dengan masyarakat setempat. Wujud penyatuan ini antara lain dari sisi fisik gedung tanpa sekat dengan pagar tembok. Untuk keperluan salat setiap harinya, juga menggunakan masjid yang ada di dukuh tersebut, bersama sama masyarakat setempat pula. Masyarakat juga diberi peluang dalam kegiatan ekonomi, misalnya menyediakan loundry bagi siswa siswi yang memerlukan. Masyarakat juga menjadi juru masak untuk menyediakan konsumsi bagi siswa dan para guru. Selain itu juga terlibat dikantin. Bahkan menurut pengurus yayasan ada tukang ojek yang melayani mobilitas siswa maupun tamutamunya dengan sergam rompi Bani Umat. Tetapi saat pengumpulan data ini dilakukan peneliti belum pernah melihat keberadaan tukang ojeg sebagaimana diungkapkan oleh pengurus yayasan tersebut. Selain kegiatan ekonomi, pada kegiatan keagamaan masyarakat juga dilibatkan. Pada sisi lain masyarakat juga ikut mengontrol perilaku siswa siswi SMP Bani Umat utamanya ketika di luar asrama.

\section{Keterpaduan Kurikulum}

Keterpaduan kurikulum yang dimaksud di sini adalah memadukan konsep kurikulum Pendidikan Nasional, Kurikulum Pesantren dan Kurikulum Khusus Kepengasuhan. Kurikulum Nasional yang dipakai adalah Kurikulum Tingkat Satuan Pendidikan (KTSP) yang meliputi mata pelajaran: Pendidikan Agama Islam, PKn, Bahasa Indonesia, Bahasa Inggris, Matematika, IPA: Kimia, Fisika dan Biologi, IPS: Geografi, Sejarah dan Ekonomi, Teknologi Informatika dan Komputer, Keterampilan: Khot (Kaligrafi), Bahasa Daerah (Bahasa Jawa) dan Bimbingan Konseling.

Adapun kurikulum kepesantrenan meliputi mata pelajaran Ilmu Fiqih yang meliputi: Fiqih, Ushul Fiqih dan Faroid. Aqidah Akhlak, meliputi: Tauhid dan Mahfudhot/ Akhlak. Al-Quran dan Hadist meliputi: Tahsinul Qiroah, Tahfidz, Tajwid, Tafsir, Tarjamah, Mutsholah Hadist dan Hadist. Bahasa Arab meliputi: Durushullughoh, Muthola'ah, Imla'/ Insya', Nahwu, Shorof dan Balaghoh. Tarbiyah dan Tarikh Islam. Sedangkan kurikulum kepengasuhan meliputi: Kajian Kitab, Mentoring (Halaqoh), Mufrodat, Muhadatsah, MTQ, Debat Bahasa Arab, Debat Bahasa Inggris, Muhadaroh, Riyadhoh dan Bimbingan Belajar.

Dari sisi tersebut, SMP IT Bina Umat, meminjam istilah Abdurahman Mas'ud, M.A., Ph.D bisa dikatakan sebagai lembaga pendidikan Islam yang kaffah. Pendidikan Islam yang masih membedakan antara ulumuddin dan ulumuddunya, belum layak disebut sebagai pendidikan Islam yang kaffah atau komprehensif. Keterpisahan antara wahyu dan akal, agama dan alam, perceraian wahyu yang tertulis, (written revelation) dan yang tak tertulis alam semesta ini (non-written revelation masih kental). ${ }^{9}$ Bukan saja dikotomi, menurut

9 Abdurahman Mas'ud. 2007. Menggagas Format Pendidikan Nondikotomik: humanisme Religius sebagai 
Jawwad Ridha, setidaknya ada tiga aliran utama dalam aliran folosofi pendidikan Islam, yaitu: 1) Aliran agamis-konservatif. Aliran ini cenderung bersikap murni keagamaan. 2) Aliran religius-rasional. Aliran ini tidak jauh berbeda dengan aliran pertama. Perbedaannya terletak pada persoalan pendidikan yang lebih bersiafat rasional-filosofis. 3) Aliran pragmatisinstrumental, yang menilai pengetahuan berdasarkan dari kegunaan praktisnya, bukan berdasarkan nilai substansialnya semata. ${ }^{10}$

Penyelenggaraan pendidikan yang memadukan antara sistem pendidikan nasional dengan model pendidikan pondok pesantren dengan meletakkan dasar-dasar pendidikan yang menyeluruh dan seimbang antara pendidikan agama dan umum, aspek kognitif, psikomotorik dan efektif telah menjadikan SMP IT Bina Umat sebagai sebuah institusi pendidikan yang sejalan dengan tujuan pendidikan nasional yaitu lembaga pendidikan yang menghasilkan manusia seutuhnya, yaitu manusia yang beriman dan bertakwa kepada Tuhan Yang Maha Esa, berakhlak mulia, sehat, berilmu, cakap, kreatif, mandiri dan menjadi warga negara yang demokratis serta bertanggungjawab sebagaimana yang dimaksudkan oleh Undang-Undang No. 20 Tahun 2003 tentang Sitem Pendidikan Nasional.

Jika dilihat konsep pendidikan yang diterapkan oleh SMP IT Bina Umat ini, telah dapat menerapkan model pendidikan yang memadukan antara penguasaan iman dan takwa serta ilmu dan teknologi dalam implementasi proses pembelajaran. Sehingga siswa-siswa yang lulus dari SMP IT Bina Umat ini akan dapat menjadi lulusan yang tidak lagi mendikotomikan antara pendidikan agama dan umum dalam memahami ilmu pengetahuan itu sendiri.

Paradigma Pendidikan Islam, cetakan ke 4. Yogyakarta: Gama Media, h. xxii

10 Abd. Haris, Kivah Aha Putra, 2012. Filsafat Pendidikan Islam, Jakarta: AMZAH. h. 120-127

\section{Keterpaduan dengan Tradisi Pesantren}

Wujud keterpaduan dengan model pesantren inilah yang menjadi kekuatan SMP Bina Umat. Pesantren merupakan satu-satunya lembaga pendidikan di Indonesia, sebelum Pemerintah kolonial Belanda memperkenalkan sekolah modern seperti yang tumbuh di Dunia Barat. Sejak itulah pendidikan terpola menjadi menjadi dua, pertama pendidikan sekolah Barat yang sekuler yang tidak mengajarkan pendidikan agama. Kedua, pendidikan yang diberikan oleh pondok pesantren yang hanya memberikan pendidikan agama saja. ${ }^{11}$ Menurut Ronald Alan Likens Bull, pondok pesantren pertama kali dirintis oleh Syaikh Maulana Malik Ibrahim pada tahun 1399 M, untuk menyebarkan Islam di Jawa. Sedangkan tokoh yang berhasil mendirikan dan mengembangkan pondok pesantren adalah Raden Rahmat (Sunan Ampel). Awalnya didirikan di Kembangkuning dengan hanya memiliki tiga santri, yaitu Wiryo Suroyo, Abu Hurairah dan Kiai Bangkuning. Beberapa waktu kemudian pindah ke Ampel Denta, Surabaya. Sejak itulah pondok pesantren mulai tumbuh dan berkembang. ${ }^{12}$ Pada masa awal berdirinya pesantren hanya dimaksudkan sebagai wahana pendidikan keagamaan. Oleh karena itu banyak pesantren yang tumbuh dari majlis ta'limmajlis ta'lim, atau pengajian-pengajian.

Cotoh pesantren-pesantren yang tumbuh dari lembaga-lembaga pengajian ialah Pesantren Tebuireng, misalnya, yang memulai kariernya dari pengajian yang diikuti oleh 8 murid. Dalam tempo 20 tahun, pengajian ini telah berkembang menjadi pesantren besar yang memiliki murid kurang lebih 200 santri dan 10 tahun kemudian, jumlah

${ }^{11}$ Maswardi. 2008. Pola dan Kebijakan Pendidikan Islam di Nusantara Pada Masa Awal Sampai Sebelum Kemerdekaan dalam Sejarah Pendidikan Islam, Editor Samsul Nizar, Kencana Prenada Media Group, Jakarta, cetakan ke-2, h. 298

${ }^{12}$ Abd. Halim Soebahar, 2013. Kebijakan Pendidikan Islam dari Ordonansi Guru Sampai UU Sisdiknas, Jakarta: PT RajaGrafindo Persada, h. 33. 
santrinya melonjak menjadi sekitar 2000 orang. Pesantren Darussalam, Blok Agung di Banyuwangi.Pesantren ini bermula dari sebuah langgar yang luasnya tidak lebih dari 34 meter persegi yang memberikan pengajian kepada 7 orang saja, karena penduduk sekitarnya, pada umumnya belum banyak mengerti dan mengerjakan ajaran Islam. 25 tahun kemudian (sampai dengan 1977) pesantren ini menjadi sebuah pesantren besar dengan jumlah santri 3177 orang. ${ }^{13}$

Juga Pondok Pesantren Modern Islam Assalaam. Bermula dari pengajian pada tahun 1976. Pengajian tersebut diperuntukkan bagi karyawan PT Tiga Serangkai. Dari pengajian ini kemudian berkembang menjadi sebuah majlis ta'lim, dikemudian hari bernama Majlis Pengajian Islam (MPI) yang pesertanya tidak hanyadarikalangankaryawanPTTigaSerangkai saja, tetapi sudah mecakup masyarakat sekitarnya. Kegiatan MPI dipusatkan di gedung MPI yang terletak di Kelurahan Punggawan, Jalan Yosodipuro nomor: 46 Surakarta. Di Punggawan inilah berbagai kegiatan dilakukan, antara lain pengajian, kursus-kursus Bahasa Arab, poliklinik, pemeliharaan fakir miskin, dan memberikan pelayanan penyelenggaraan janazah. Dalam mengembangkan pendidikan, MPI mendirikan Madrasah Diniyah Awaliyah (MDA). MDA memberikan pendidikan agama Islam untuk menambah pendidikan agama Islam bagi siswa-siswi Sekolah Dasar (SD). Pelaksanaan kegiatan pembelajarannya diselenggarakan pada sore hari, setelah mereka pulang dari sekolah. Terdorong oleh keberhasilan MDA maka pengurus yayasan menggagas bentuk lembaga pendidikan lainnya, yakni Madrasah Tsanawiyah (MTs). Tepatnya pada tanggal: 7 Agustus 1982, berdirilah sebuah MTs, yang dipimpin oleh K.H. Muhammad Chozin Siddiq sebagai kepala MTs. Walaupun madrasah ini merupakan sekolah formal, tetapi oleh yayasan MPI dikembangkan

${ }^{13}$ Zamakhsyari Dhofier. 1982. Tradisi Pesantren, Studi Tentang Pandangan Hidup Kyai, Jakarta: LP3ES, h. 33. kebijakan dengan model mengasramakan para siswanya. ${ }^{14}$

SMP IT Bina Umat yang memadukan model pondok pesantren membangun konsep kehidupan bersama antara siswa dan guru. Di samping sebagai tenaga pengajar, guru juga bertindak sebagai orang tua. Di mana siswa hidup secara bersama-sama dengan guru dalam suatu lingkungan. Kemudian juga dibangun kehidupan yang islamis dan saling membantu (kakak kelas membantu adik kelas). Jiwa kepemimpinan juga dibangun mulai dari bergilir menjadi pimpinan kamar di asrama, kakak kelas membina adik kelas dan lain sebagainya. Siswa diwajibkan tinggal di asrama selama 24 jam dan dibina oleh guru, ustadz dan uztadzah.

Pesantren memiliki kultur yang unik, berdiri sebagai subkultur tersendiri, tidak menjadi bagian dari struktur pemerintahan desa, kecamatan atau pemerintahan yang lebih tinggi. Berbeda dengan sekolah yang menjadi bagian dari sistem pendidikan nasional. Kemandirian pondok pesantren baik secara kelembagaan dan secara sosial-keagamaan berperan sebagai panutan umat. Tradisi pesantren yang dipadukan oleh SMP Bina Umat ini antara lain:

a. Aspek Ubudiyah

Ubudiyah dalam dalam pengertian menunaikan perintah Allah dalam kehidupan sehari-hari dengan melaksanakan tanggung jawab sebagai hamba Allah. Ubudiyah bukan hanya sekedar ibadah biasa, tetapi ubudiyah yang penuh dengan rasa penghambaan, pengabdian hanya kepada Allah semata, sehingga memiliki muatan rasa takut, tawadhu', rendah hati, sabar dan sebagainya.

1) Untuk itu SMP Bina Umat mempunyai aturan-aturan tentang tentang

${ }^{14}$ Disadur dari M.T. Arifin dan Asrowi. 1994. Potret Pesantren, Eksperimentasi dan Perspektif Pondok Perkotaan di Pondok Pesantren Modern Islam Assalaam Surakarta, Solo: PT Tiga Serangkai. h. 25-50. 
kewajiban siswa untuk melaksanakan shalat-shalat fardlu secara berjamaah, maupun salat malam, salat dhuha dan seterusnya. Jadi di dalam mengerjakan ibadah siswa dituntun oleh para pengasuh agar hatinya dipenuhi rasa pengehambaan dan pengabdian hanya kepada Allah semata.

2) Para siswanya diberi tugas secara bergilir dalam pengorganisasian kegiatan ubudiyah. Tugas secara bergilir ini salah satu maknanya adalah melatih tanggungjawab. Sekolah memang memiliki peran besar dalam mengembangkan pribadi yang bertanggungjawab. Dengan bimbingan guru dan pengasuh siswa dilatih dan dibiasakan untuk dapat bertanggungjawab dan juga mempertanggungjawabkanb ucapan, sikap, perbuatan pada dirinya sendiri, lebih jauh nantinya juga kepada masyarakat, bangsa, dan negara.

\section{b. Aspek Mua'malah}

1) Para siswa SMP Bina Umat diwajibkan berpakaian muslim, dan dilarang membawa alat IT seperti HP, televisi. Wajib menjaga ukhuwah islamiyah,

2) Kontrol pergaulan di lingkungan SMP Bina Umat dilakukan dengan penerapan peraturan yang ketat. Kontrol dilakukan oleh para pengasuh, dan siswa secara bergilir. Tugastugas siswa dalam asrama sekolah juga ditetapkan secara bergilir di kalangan siswa, baik tugas kebersihan, keamanan, adzan, termasuk pergantian anggota kamar (tempat menginap). Bahkan masyarakat setempat juga ikut ambil andil dalam mengontrol perilaku siswa, terutama ketika berada di luar asrama.

3) Adaaturanjammakan, belajar, istirahat, mengaji, piket, dan seterusnya yang membuat siswa menjadi terlatih dalam bekerjasama, dan menjadi siswa yang bertanggungjawab atas kewajibannya.

\section{c. Aspek Pendidikan Kepesantrenan}

1) Cita-cita SMP Bina Umat adalah menghasilnya manusia unggul untuk menggapai kebahagiaan duniawi dan ukhrawi. Ini merupakan terjemahan semangat tafaquh fiddin. Selain itu para siswanya sejak awal sudah memiliki tujuan ingin mempelajari ilmu-ilmu agama dan juga ilmu pengetahuan umum.

2) Dengan model pesantren SMP Bina Umat menjamin bahwa perilaku peserta didk dapat lebih berakhlaqul karimah dibanding dengan model pendidikan sekolah. Karena dengan model asrama, seperti pondoknya para santri di pesantren, maka kontrol dari pengasuh dapat dilakukan selama 24 jam. Selain itu perilaku para ustadz juga menjadi panutan para siswanya.

3) Selain diajarkan ilmu keagamaan, ilmu pengetahuan umum di SMP Bina Umat juga diajarkan pendidikan keterampilan seperti menjahit, bertani, berternak, beladiri, sebagaimana lazimnya di pondok pesantren. Pendidikan keterampilan ini sudah merupakan kebutuhan agar siswa nantinya memilki keterampilan yang relevan dengan peluang dan kesempatan yang ada.

\section{d. Kepemimpinan}

1) Tumbuhnya kultur kepemimpinan kolektif yang mengandalkan solidaritas, kerjasama, kecerdasan, strategi, dan daya juang yang tak kenal lelah. Maka di sana ada aturan jam makan, belajar, istirahat, mengaji, piket, tugas secara bergilir dan seterusnya yang membuat 
siswa menjadi terlatih dalam bekerjasama, dan menjadi siswa yang bertanggungjawab atas kewajibannya.

2) Tradisi rasa hormat kepada ustadz/ guru dan siswa senior ditanamkan di SMP Bina Umat, sebagaimana tradisi pesantren. Penanaman rasa hormat ini berarti diajarkan untuk mengakui pentingnya nilai-nilai kemanusiaan, seperti menghormati hak asasi orang lain, peduli terhadap orang lain, berusaha membangun perdamaian dan kedamaian utamanya di lingkungan sekolah dan ke depan tentu bagi seluruh umat manusia.

3) Keteladanan menjadikata kunci yang kuat dari aspek kepemimpinan di SMP Bina Umat. Keteladanan inilah salah kultur pesantren yang dicoba ditumbuhkembangkan di SMP Bina Umat. Dengan nilai-nilai keteladanan tersebut siswa diharapkan mampu menempuh kehidupan yang benar dan kebal terhadap racun kerusakan moral dan penyakit sosial lainya.

4) Ketaatan kepada ustadz/guru adalah bagian dari disiplin tradisi pesantren yang juga diadopsi SMP Bina Umat. Azas ketaatan ini memang sudah dimulai sejak dari lingkungan keluarga. Ketaatan kepada ustadz/ guru merupakan bagian dari disiplin tradisi pesantren untuk mewujudkan perilaku yang santun, tertib dan disiplin, peduli terhadap sesama dan lingkungan serta sabar, ulet dan pemberani dalam menghadapi permasalahan hidup sehari-hari.

\section{e. Kelembagaan}

1) Kemandirian SMP Bina Umat, di topang spirit kemandirian sebagaimana layaknya pesantren yang pada umumnya memiliki usaha.
SMP IT Bina Umat ditopang salah satunya ditopang $\mathrm{KBIH}$ Bina Umat, yang pengahsilan dari dana $\mathrm{KBIH}$ tersebut diperuntukkan untuk biaya operasional sekolah.

2) Keberadaan dan keberlanjutan SMP Bina Umat tidak lepas dari dukungan umat, baik masyarakat sekitar maupun masyarakat luas. Sebagaimana dijelaskan sebelumnya pada awal berdirinya SMP Bina Umat tidak bisa dilepaskan dari $\mathrm{H}$. Bajuri yang mewakafkan tanah beserta rumahnya.

Dari beberapa karakteristik tersebut di atas dapat disimpulkan ada empat ciri utama yang diadopsi SMP Bina Umat. Pertama model pesantren, dengan mengasramakan siswa adalah mengadopsi santri mukim di pesantren. Kedua, model pembelajaran selain klasikal adalah bandongan dan sorogan, terutama untuk materi keagamaan. Ketiga interaksi guru/ustdaz yang memberikan pendidikan, bimbingan, pengayoman selama 24 jam. Ini berbeda dengan model sekolah yang hanya paruh waktu interkasi guru dan siswa. Keempat, banyak nilai-nilai kepesantrenan yang dicoba ditanamkan di sini, antara lain nilai ubudiyah, muamalah, kepemimpinan, kemandirian, kesalehan, keteladanan, kedisiplinan, kesederhanaan, toleran, rendah hati, tolong-menolong, dan lain sebagainya.

\section{Keterpaduan Pembelajaran di dalam dan di luar kelas}

Untuk menunjang proses pembelajaran dan memfasilitasi para siswa agar mampu berbahasa Inggris dan Arab dengan lancar, SMP IT Bina Umat membentuk divisi bahasa yang bertugas mengurusi di bidang kebahasaan. Divisi Bahasa inilah yang bertanggung-jawab dalam penyelenggaraan kegiatan ekstrakurikuler Bahasa Inggris dan ekstrakurikuler Bahasa Arab. 
Pelaksanaan ektrakurikuler Bahasa Inggris dan Bahasa Arab, dalam prakteknya dikelola oleh OSIS. Setiap minggunya di papan pengumuman dituliskan daftar vocabularies Bahasa Inggris maupun Bahasa Arab yang harus dihafalkan dan dipraktekkan penggunaannya oleh siswa. Selanjutnya dilaksanakan pekan bahasa sebagai wahana bagi siswa untuk unjuk kebolehan berbicara menggunakan kedua bahasa tersebut. Pekan Bahasa ini dilaksanakan setiap minggu sekali. Dalam Pekan Bahasa ini para siswa juga melaksanakan kegiatan muhadharoh atau ceramah dengan menggunakan Bahasa Arab maupun Bahasa Inggris. Sarana penunjang proses pembelajaran Bahasa Inggris, SMP IT Bina Umat memang belum begitu memadai. Namun sekolah memiliki sumber belajar yang cukup memadai berupa buku English Conversation, buku-buku paket penunjang pelajaran Bahasa Inggris, beberapa simplified English novel dan CD pembelajaran Bahasa Inggris. Untuk pembelajaran Bahasa Arab, fasilitas yang dimiliki oleh SMP IT Bina Umat masih terbatas. Sekolah hanya memiliki beberapa CD pembelajaran Bahasa Arab dan beberapa buku muhadatsah. Sekolah juga memiliki beberapa tape recorder sebagai media penunjang proses KBM Bahasa.

Untuk proses pembelajaran Tahfidz, SMP IT Bina Umat melaksanakan dua model pembelajaran. Pada saat pembelajaran Tahfidz pada KBM di sekolah, siswa mendapatkan beberapa teori \& tehnik untuk menghafal AlQur'an. Di sini siswa juga diuji hafalannya secara tertulis. Sedangkan untuk mengecek sejauh mana hafalan yang telah dicapai siswa, dilaksanakan setiap habis shalat subuh dan setelah shalat maghrib. Pada kesempatan ini, siswa membentuk halaqah yang terdiri dari 10 sampai dengan 15 siswa berdasarkan level bacaan yang telah mereka kuasai, yang dipandu oleh seorang ustadz/ustadzah yang mengampu Tahfidz. Dalam kegiatan halaqoh ini, siswa menyetor hafalan yang mereka capai kepada ustadz/ustadzah. Setoran hafalan ini tergantung pada kesiapan masing-masing siswa. Apabila siswa telah siap, maka siswa tersebut dapat segera menyetorkan bacaannya pada saat halaqoh, namun apabila belum siap siswa yang bersangkutan menyetorkan bacaannya pada halaqoh berikutnya. Tugas ustadz/ustadzah di halaqoh ini selain menerima setoran bacaan siswa dan mencatatnya di kartu progress, mereka juga melakukan koreksi/ evaluasi terhadap kemajuan hafalan siswa.

Intinya, pembelajaran dilaksanakan secara terpadu antara kegiatan di dalam kelas dan di luar kelas. Kegiatan berfikir dan kegiatan ruhiyah, memadukan antara iman dan takwa dengan ilmu pengetahuan dan teknologi. Oleh karena itu SMP Bina Umat mematok siswanya setelah lulus harus hafal Al-Qur'an sebanyak tiga juz. Selain hafal tiga juz mereka juga diharapkan mahir berbahasa arab atau inggris. Untuk itu kita lihat hasilnya sebagaimana tabel berikut.

Tabel 1:

Jumlah Juz yang Sudah Dihafal.

\begin{tabular}{|l|r|r|r|r|r|r|}
\hline Kelas & $\begin{array}{c}\text { Lebih } \\
\text { dari tiga } \\
\text { juz }\end{array}$ & Tiga juz & Dua juz & Satu juz & $\begin{array}{c}\text { Kurang } \\
\text { dari satu } \\
\text { juz }\end{array}$ & Total \\
\hline \multirow{2}{*}{ VII } & 0 & 0 & 4 & 8 & 14 & 26 \\
\cline { 2 - 7 } & $.0 \%$ & $.0 \%$ & $4.0 \%$ & $8.1 \%$ & $14.1 \%$ & $26.3 \%$ \\
\hline \multirow{2}{*}{ VIII } & 4 & 2 & 14 & 20 & 0 & 40 \\
\cline { 2 - 7 } & $4.0 \%$ & $2.0 \%$ & $14.1 \%$ & $20.2 \%$ & $.0 \%$ & $40.4 \%$ \\
\hline \multirow{2}{*}{ IX } & 5 & 10 & 15 & 3 & 0 & 33 \\
\cline { 2 - 7 } & $5.1 \%$ & $10.1 \%$ & $15.2 \%$ & $3.0 \%$ & $.0 \%$ & $33.3 \%$ \\
\hline Total & 9 & 12 & 33 & 31 & 14 & 99 \\
\hline & $9.1 \%$ & $12.1 \%$ & $33.3 \%$ & $31.3 \%$ & $14.1 \%$ & $100.0 \%$ \\
\hline
\end{tabular}

Dari tabel di atas ternyata kelas IX baru $15 \%$ dari siswa yang sudah menguasai Al-Qur'an sebanyak tiga juz atau lebih. Padahal ketika penelitian ini dilaksanakan hanya sekitar satu semester lagi siswa kelas sembilan tersebut lulus dari SMP. Artinya diperlukan usaha yang kuat dan kera agar target tersebut tercapai.

Selain hafal tiga juz setelah lulus, mereka juga diharapkan mahir dalam dua bahasa, yakni Bahasa Arab dan Inggris. Tabel berikut dapat memberikan gambaran tentang tingkat 
kepahaman dalam membaca buku berbahasa Inggris.

Tabel 2:

Tingkat Kepahaman dalam Membaca Buku Berbahasa Inggris

\begin{tabular}{|c|c|c|c|c|c|}
\hline \multicolumn{2}{|l|}{ Kelas } & $\begin{array}{l}\text { Paham } \\
85 \% \text { s/d 100\% }\end{array}$ & \begin{tabular}{|l|} 
Paham \\
$65 \%$ s/d $84 \%$
\end{tabular} & Paham $\leq 64 \%$ & Total \\
\hline \multirow{2}{*}{\multicolumn{2}{|c|}{ VII }} & 4 & 20 & 2 & 26 \\
\hline & & $4.0 \%$ & $20.2 \%$ & $2.0 \%$ & $26.3 \%$ \\
\hline \multirow{2}{*}{\multicolumn{2}{|c|}{ VIII }} & 6 & 28 & 6 & 40 \\
\hline & & $6.1 \%$ & $28.3 \%$ & $6.1 \%$ & $40.4 \%$ \\
\hline \multirow{2}{*}{\multicolumn{2}{|c|}{ IX }} & 1 & 19 & 13 & 33 \\
\hline & & $1.0 \%$ & $19.2 \%$ & $13.1 \%$ & $33.3 \%$ \\
\hline \multirow[t]{2}{*}{ Total } & & 11 & 67 & 21 & 99 \\
\hline & & $11.1 \%$ & $67.7 \%$ & $21.2 \%$ & $100.0 \%$ \\
\hline
\end{tabular}

Bila seorang siswa membaca buku berbahasa inggris, kemudian sudah bisa memahami sekitar $85 \%$ dari isi buku tersebut, dianggap penguasaan Bahasa Inggrisnya sudah baik, maka tabel tersebut di atas menjelaskan bahwa $1 \%$ dari siswa kelas IX yang dianggap sudah bagus tingkat penguasaannya. Bila dilihat dari seluruh siswa SMP Bina Umat, maka baru sekitar $11 \%$ saja yang penguasaan Bahasa Inggrisnya sudah bagus. Lalu bagaimana dengan tingkat penguasaan Bahasa Arab, tabel berikut dapat memberikan gambaran tentang tingkat kepahaman dalam membaca buku berbahasa Arab.

Tabel 3:

Tingkat Kepahaman dalam Membaca Buku Berbahasa Arab

\begin{tabular}{|c|r|r|r|l|}
\hline \multirow{2}{*}{ Kelas } & $\begin{array}{c}\text { Paham } \\
85 \% \mathrm{~s} / \mathrm{d} \\
100 \%\end{array}$ & $\begin{array}{c}\text { Paham } \\
65 \% \mathrm{~s} / \mathrm{d} 84 \%\end{array}$ & $\begin{array}{c}\text { Paham } \leq \\
64 \%\end{array}$ & \multicolumn{2}{l|}{ Total } \\
\hline \multirow{2}{*}{ VII } & 4 & 20 & 2 & 26 \\
\cline { 2 - 5 } & $4.0 \%$ & $20.2 \%$ & $2.0 \%$ & $26.3 \%$ \\
\hline \multirow{2}{*}{ VIII } & 13 & 23 & 4 & 40 \\
\cline { 2 - 5 } & $13.1 \%$ & $23.2 \%$ & $4.0 \%$ & $40.4 \%$ \\
\hline IX & 5 & 21 & 7 & 33 \\
\cline { 2 - 5 } & $5.1 \%$ & $21.2 \%$ & $7.1 \%$ & $33.3 \%$ \\
\hline Total & 22 & 64 & 13 & 99 \\
\hline & $22.2 \%$ & $64.6 \%$ & $13.1 \%$ & $100.0 \%$ \\
\hline
\end{tabular}

Dari tabel tersebut di atas terlihat sekitar 5\% persen siswa kelas IX yang sudah dapat dikatakan penguasaan Bahasa Arabnya bagus. Sementara kalau dilihat dari seluruh siswa di SMP Bia Umat, ternya yang penguasaan Bahasa Arabnya sudah bagus baru sekitar $22 \%$ saja.

SMP Bina Umat mengadopsi model pesantren. Pondok Pesantren oleh Gus Dur didefinisikan sebagai "tempat tinggal santri". Santri merupakan unsur dari penghuni pondok pesantren. Pondok pesantren menjadi rumah yang lain bagi santri. Model pondok pesantren sangat berbeda dengan sekolah, di mana interaksi dan perhatian pihak sekolah dengan para siswanya secara paruh waktu, maka di pondok pesantren sepenuhnya dipercayakan dan menjadi tanggung jawab pondok pesantren.

Pemilihan model pesantren ini bisa membawa kosekuensi prestasi sekolah lemah dan juga pembelajaran di pesantrennya lemah. Bisa jadi karena hal ini disebabkan karena beban sebagaimana tercermin dalam jadwal SMP Bina Umat yang begitu padat. Namun bisa juga mutu sekolah baik, tetapi penguasaan materi agama menjadi lemah. Atau bisa sebaliknya prestasi sekolahnya rendah, tetapi memiliki kekuatan pada penguasaan materi keagamaan. Dalam hal ini SMP Bina Umat ingin menggapai dua-duanya, yakni prestasi sekolahnya bagus tetapi secara bersamaan penguasaan materi kepesantrenan juga bagus. Tentu kalau demikian perlu sumberdaya yang memadai, dan proses pembelajaran juga yang ditunjang dengan alat bantu pebelajaran yang optimal.

\section{PENUTUP}

\section{Kesimpulan}

Sekolah Islam terpadu menarik minat masyarakat karena, pertama, bahwa ummat Islam tidak akan mengabaikan nilainilai Islam yang menjadi sumber ajaran moral. Kedua, masyarakat mulai mempertanyakan keberhasilan sekolah dalam 
hal memoralkan siswanya. Sekolah memang berhasil mencerdaskan siswa, tetapi apakah sudah berhasil dalam membangun moralnya. Munculnya, Sekolah Islam Terpadu menawarkan sesuatu hal yang lebih bila dibandingkan dengan sekolah umum. Selain mengintegrasikan pendidikan agama dengan pendidikan umum, Sekolah Islam Terpadu juga memberikan kepada siswanya berbagai keterampilan yang tidak ditawarkan oleh sekolah.

SMP Bina Umat mengadopsi model pesantren dalam penyelenggaraan pendidikannya. Pesantren memiliki kultur yang unik, berdiri sebagai subkultur tersendiri, tidak menjadi bagian dari struktur pemerintahan desa, kecamatan atau pemerintahan yang lebih tinggi. Berbeda dengan sekolah yang menjadi bagian dari sistem pendidikan nasional. Tradisi pesantren yang diadopsi oleh SMP Bina Umat ini antara lain: 1) Aspek Ubudiyah. 2) Aspek Mua'malah. 3) Aspek Pendidikan Kepesantrenan. 4) Kepemimpinan (leadership. 5). Kelembagaan.

\section{Rekomendasi}

Rekomendasi untuk peningkatan penguasaan bahasa asing siswa: 1). Diharapkan adanya peningkatkan jumlah koleksi bukubuku penunjang pembelajaran Bahasa Inggris maupun Bahasa Arab, terutama sekali buku-buku yang berkaitan dengan English Conversation dan Muhadatsah. 2). Metode pembelajaran English Conversation dan Muhadatsah hendaknya tidak hanya terbatas pada pemberian daftar vocabularies yang harus dihafal dan dipraktekkan oleh siswa. 3). Pembiasaan mendengarkan percakapan Bahasa Inggris dan Bahasa Arab oleh penutur asli melalui media rekaman (kaset atau CD) dapat dilakukan setiap hari minimal 30 menit sembari siswa melaksanakan kegiatan harian mereka (seperti: mencuci pakaian atau membersihkan kamar), agar siswa terbiasa dengan ungkapanungkapan dan ekspresi bahasa yang digunakan sehari-hari oleh penutur asli. Dengan metode ini akan mempercepat proses pembelajaran berbicara menggunakan bahasa asing. 4). Praktek berbicara menggunakan bahasa asing (Bahasa Inggris dan Arab) hendaknya tidak hanya dilakukan pada saat Pekan Bahasa. Namun bisa dilaksanakan pada hari-hari tertntu yang sudah dijadwalkan sebagai wahana melatih keterampilan berbahasa asing. Sebagai contoh: Siswa diwajibkan menggunakan Bahasa Indonesia setiap hari Senin dan Rabu, Bahasa Inggris setiap hari Selasa dan Kamis, Bahasa Arab setiap hari Jum'at dan Sabtu, dan Bahasa Jawa Kromo setiap hari Minggu. Dengan metode ini diharapkan kemampuan siswa untuk berkomunikasi menggunakan bahasa asing maupun bahasa lokal akan meningkat. 5). Sekolah diharapkan menjalin kerjasama dengan lembaga lain, terutama sekali lembaga pendidikan bahasa asing seperti lembaga kursus Bahasa Inggris dan Arab, ataupun perguruan tinggi yang menyelenggarakan pendidikan bahasa asing.

\section{DAFTAR PUSTAKA}

Abd. Halim Soebahar (2013): Kebijakan Pendidikan Islam dari Ordonansi Guru Sampai UU Sisdiknas, Jakarta: PT RajaGrafindo Persada.

Abd. Haris (2012): Kivah Aha Putra, S.P.I. Filsafat Pendidikan Islam, Jakarta: AMZAH.

Abd. Majid (2013):. Pendidikan Berbasis Ketuhanan, Bandung: VC. Maulana Media Grafika, cetakan ke 3..

Abdurahman Mas'ud (2007): Menggagas Format Pendidikan Nondikotomik: humanisme Religius sebagai Paradigma Pendidikan Islam, cetakan ke 4. Yogyakarta: Gama Media.

Alwi Shihab (1998): Islam Inklusif, Bandung: Mizan, cetakan ke tiga.

Arifin, MT, dan Asrowi, (1994): Potret Pesantren, Eksperimentasi dan Perspektif Pondok Perkotaan di Pondok Pesantren Modern Islam Assalaam Surakarta, Solo: PT Tiga Serangkai. 
http://sditsalmanalfarisi2.wordpress. com/2012/02/07/pengertian-sekolahislam-terpadu/ diakses tanggal 10 Februari 2014.

http://smait.nurhidayahsolo.com/berita180-konsep-sekolah-islam-terpadu.html diakses tanggal 10 Februari 2014.

Maswardi (2008): Pola dan Kebijakan Pendidikan Islam di Nusantara Pada Masa Awal Sampai Sebelum Kemerdekaan dalam Sejarah Pendidikan Islam, Editor Samsul Nizar, Kencana Prenada Media Group, Jakarta, cetakkan ke 2.

Zamakhsyari Dhofier (1988): Tradisi Pesantren, Studi Tentang Pandangan Hidup Kyai, Jakarta: LP3ES. 